REFLEKSI HUKUM

Jurnal Imu Hukum
p-ISSN 2541-4984 | e-ISSN 2541-5417

Volume 5 Nomor 1, Oktober 2020, Halaman 43-62

DOI: https://doi.org/10.24246/jrh.2020.v5.i1.p43-62

Open access at: http://ejournal.uksw.edu/refleksihukum

Penerbit: Fakultas Hukum Universitas Kristen Satya Wacana

\title{
IMPLIKASI PUTUSAN MAHKAMAH KONSITUSI NOMOR 18/PUU-XVII/2019 TERHADAP PELAKSANAAN EKSEKUSI LEMBAGA JAMINAN
}

\author{
Eko Surya Prasetyo \\ Pascasarjana Universitas Airlangga \\ Korespondensi: ekosuryaprasetyo@gmail.com
}

Naskah diterima: 15 April 2020|Direvisi: 8 Mei 2020|Disetujui: 30 Oktober 2020

\begin{abstract}
Abstrak
Objek jaminan fidusia merepresentasikan pentingnya prinsip kepercayaan kreditor kepada debitor. Pada dasarnya, Undang-Undang Fidusia memberikan kreditor hak menjual objek jaminan fidusia apabila debitor cidera janji. Namun, Putusan Mahkamah Konstitusi Nomor 18/PUU-XVII/2019 mengurangi hak tersebut dengan pemberian syarat adanya kesepakatan cidera janji antara kreditor dan debitor serta kerelaan debitor untuk menyerahkan objek jaminan. Tulisan ini mengkaji pertimbangan dalam Putusan tersebut ditinjau dari hak kebendaan serta implikasinya terhadap pelaksanaan eksekusi fidusia. Metode yuridis normatif dengan pendekatan perundang-undangan dan konseptual digunakan dalam tulisan ini. Pada kesimpulannya, Putusan tersebut bertentangan dengan prinsip hak kebendaan terutama asas droit de suite, droit de preference, dan parate executie. Implikasinya berpotensi berpengaruh terhadap waktu, biaya, dan penambahan beban baru dalam pelaksanaan eksekusi objek jaminan. Sebagai rekomendasi jangka panjang pembentuk undang-undang perlu melakukan perubahan UU Fidusia dengan penegasan kekuatan eksekutorial dalam jaminan fidusia, serta untuk jangka pendek perlu adanya perubahan klausul akta perjanjian dan mengoptimalkan mekanisme gugatan sederhana.
\end{abstract}

\section{Kata-kata Kunci: Jaminan Fidusia; Kekuatan Eksekutorial; Cidera Janji.}

\section{Abstract}

The object of fiduciary security represents how important the principle of trust of the creditor is. Under the Fiduciary Law, creditors own rights to sell fiduciary collateral objects if the debtor is in breach of contract. Unfortunately, the Constitutional Court Decision No. 18/PUUXVII/2019 reduced this right by granting the terms of the agreement of breach of contract and the debtor's willingness to surrender the object of collateral. This paper reviewed the Decision highlighting material rights and their implications for the insurance institution. A normative juridical method using a statutory and conceptual approach was applied to conclude that the Decision is incompatible with the principle of material rights, especially the principle of droit de suite, droit de preference, and separate executive. It affects the time, cost, and the addition of new burdens in the execution of the collateral object execution. As a longterm recommendation, legislators need to amend the Fiduciary Law by affirming the executive power in fiduciary guarantees. Additionally, a change in the agreement deed clause and an effort to optimize the simple lawsuit mechanism are needed as a short-term recommendation.

Keywords: Fiduciary Guarantee; Executive Power; Breach of Contract. 


\section{PENDAHULUAN}

Jaminan fidusia merupakan hak jaminan kebendaan ${ }^{1}$ yang mengalihkan kepemilikan atas suatu benda yang dijadikan jaminan dari Pemberi Fidusia (debitor) kepada Penerima Fidusia (kreditor) tanpa ada perpindahan atas penguasaan secara fisik benda tersebut (constitutum possesorium) sehingga pemilik masih dapat menguasai benda tersebut hanya saja kepemilikannya secara sementara beralih ke kreditor hingga debitor menyelesaikan kewajiban utangnya. Dengan demikian debitor tetap dapat memanfaatkan bendanya untuk kebutuhan sehari-hari atau kebutuhan usahanya, sehingga jaminan ini tidak mematikan produktivitas debitor.

Sebagai bukti pemegang jaminan fidusia, kreditor akan menerima Sertifikat Jaminan Fidusia. Dengan Sertifikat ini, kreditor memiliki hak menjual benda yang menjadi objek jaminan fidusia atas kekuasaannya sendiri apabila debitor cidera janji. ${ }^{2} \mathrm{Hal}$ ini ditandai dengan pencantuman katakata "DEMI KEADILAN BERDASARKAN KETUHANAN YANG MAHA ESA" dalam Sertifikat Jaminan Fidusia, ${ }^{3}$ sehingga mempunyai kekuatan eksekutorial yang sama dengan putusan pengadilan yang telah berkekuatan hukum tetap 4 . Kekuatan eksekutorial dalam Sertifikat Jaminan Fidusia artinya bahwa eksekusi langsung dapat dilaksanakan tanpa melalui pengadilan dan bersifat final serta mengikat para pihak untuk melaksanakan putusan tersebut. 5

Kekuatan eksekutorial dalam Sertifikat Jaminan Fidusia mengalami perubahan makna setelah Putusan MK Nomor 18/PUU-XVII/2019 yang menguji konstitusionalitas Pasal 15 ayat $(2)^{6}$ dan ayat (3) ${ }^{7}$ Undang-Undang Nomor 42 Tahun 1999 tentang Jaminan Fidusia (selanjutnya disebut UU No. 42 Tahun 1999), yang diajukan oleh Aprilliani Dewi dan Suri Agung Prabowo (selanjutnya disebut Pemohon). 8 Mahkamah Konstitusi (selanjutnya disebut MK) memutuskan frasa "kekuatan eksekutorial" dan frasa "yang sama dengan putusan pengadilan yang berkekuatan hukum tetap" inkonstitusional apabila tidak dimaknai "terhadap jaminan fidusia yang tidak ada kesepakatan tentang cidera janji (wanprestasi) dan debitor keberatan menyerahkan secara sukarela objek yang menjadi jaminan fidusia, maka segala mekanisme dan prosedur hukum dalam pelaksanaan eksekusi Sertifikat Jaminan Fidusia harus dilakukan dan berlaku sama dengan pelaksanaan eksekusi putus-

Pasal 1 angka 2 UU No. 42 Tahun 1999.

Pasal 15 ayat (3) UU No. 42 Tahun 1999.

Pasal 15 ayat (1) UU No. 42 Tahun 1999.

Pasal 15 ayat (2) UU No. 42 Tahun 1999.

Badriyah Harun, Penyelesaian Sengketa Kredit Bermasalah, Solusi Hukum (Legal Action) dan Alternatif Penyelesaian Segala Jenis Kredit Bermasalah (Pustaka Yustisia 2010) 89-90.

$6 \quad$ Pasal 15 ayat (2) UU No. 42 Tahun 1999 berbunyi: "Sertifikat Jaminan Fidusia sebagaimana dimaksud dalam ayat (1) mempunyai kekuatan eksekutorial yang sama dengan putusan pengadilanyang telah memperoleh kekuatan hukum tetap"

$7 \quad$ Pasal 15 ayat (3) UU No. 42 Tahun 1999 berbunyi: "Apabila debitor cidera janji Penerima Fidusia mempunyai hak untuk menjualBenda yang menjadi objek Jaminan Fidusia atas kekuasaannya sendiri."

$8 \quad$ Adhi Wicaksono, 'Putusan MK: Penarikan Barang Leasing Harus Melalui Pengadilan' CNN Indonesia (Jakarta, 13 Januari 2020) <https://www.cnnindonesia.com/nasional/20200113 112552-12-464820/putusan-mk-penarikan-barang-leasing-harus-melalui-pengadilan> diakses 22 April 2020. 
an pengadilan yang telah berkekuatan hukum tetap". Begitu pula frasa "cidera janji" dinilai inkonstitusional apabila tidak dimaknai bahwa "adanya cidera janji tidak ditentukan secara sepihak oleh kreditor melainkan atas dasar kesepakatan antara kreditor dengan debitor atau atas dasar upaya hukum yang menentukan telah terjadinya cidera janji". ${ }^{9}$ Dengan putusan tersebut, Sertifikat Jaminan Fidusia akan kehilangan kekuatan eksekutorial yang sama dengan putusan pengadilan yang telah memperoleh kekuatan hukum apabila tidak memenuhi syarat pertama, terdapat kesepakatan tentang cidera janji (wanprestasi), dan kedua, debitor secara sukarela menyerahkan objek jaminan. ${ }^{10}$ MK berpendapat bahwa, pertama, Pasal 15 ayat (2) UU No. 42 Tahun 1999 tidak mencerminkan adanya pemberian perlindungan hukum yang seimbang antara kreditor dan debitor. ${ }^{11}$ Kedua, substansi norma dalam Pasal 15 ayat (3) UU No. 42 Tahun 1999 tidak memberikan kepastian hukum tentang kapan cidera janji itu dianggap telah terjadi dan siapa yang berhak menentukan.

Menyikapi Putusan MK Nomor 18/ PUU-XVII/2019, penelitian ini akan menjawab permasalahan yang menjadi pertimbangan MK dalam putusan tersebut yakni, pertama, bagaimana perlindungan hukum yang diberikan dalam Sertifikat Jaminan Fidusia. Kedua, bagaimana implikasi Putusan MK ditinjau dari asas hukum kebendaan jaminan fidusia. Ketiga, bagaimana implikasi Putusan MK terhadap proses eksekusi objek jaminan fidusia.

\section{PEMBAHASAN}

\section{Perlindungan Hukum yang Seimbang dalam Sertifikat Jaminan Fidusia}

Jaminan fidusia merupakan bentuk perikatan antara kreditor dan debitor yang lahir dari perjanjian. Jaminan fidusia merupakan perjanjian ikutan dari suatu perjanjian pokok $^{12}$ dalam hal ini perjanjian pinjam meminjam. Jaminan fidusia sebagai jaminan utang dilakukan melalui tiga tahapan yaitu, fase pertama, fase perjanjian obligator adalah perjanjian berupa pinjam meminjam uang antara kreditor dan debitor. Fase kedua, fase perjanjian kebendaan adalah penyerahan hak milik dari debitur kepada kreditur dilakukan dengan cara constitutum posessorium yaitu penyerahan hak milik sebagai objek jaminan fidusia tanpa menyerahkan fisik dari benda jaminan, dan fase ketiga, fase perjanjian pinjam pakai adalah perjanjian bahwa debitor tetap dapat menguasai secara fisik objek jaminan fidusia. ${ }^{13}$ Jaminan fidusia sebagai bentuk perjanjian harus memenuhi syarat sahnya perjanjian sebagaimana Pasal 1320 KUH Perdata yakni kesepakatan mereka yang mengikatkan diri, kecakapan untuk membuat suatu perikatan, suatu pokok persoalan tertentu, dan suatu sebab yang tidak ter-

9 Putusan Mahkamah Konstitusi Republik Indonesia Nomor 18/PUU-XVII/2019, Mahkamah Konstitusi, 6 Januari 2020.

10 Y. Sogar Simamora, 'Prinsip Eksekutabilitas Atas Jaminan Fidusia Pasca Putusan MK' (Seminar Jaminan Fidusia Pasca Putusan Mahkamah Konstitusi, Surabaya, Februari 2020).

11 Putusan Mahkamah Konstitusi Republik Indonesia Nomor 18/PUU-XVII/2019, Mahkamah Konstitusi, 6 Januari 2020.

Pasal 4 UU No. 42 Tahun 1999.

13 Munir Fuady, Hukum Bisnis Dalam Teori dan Praktek (Ed. 1, Citra Aditya Bakti 1996) 191. 
larang. Syarat kesatu dan kedua disebut syarat subjektif karena terkait tentang para pihak yang mengadakan perjanjian, sedangkan syarat ketiga dan keempat disebut syarat objektif karena terkait tentang objek perjanjian. Apabila syarat subjektif tidak dipenuhi maka dapat diajukan pembatalan perjanjian, sedangkan apabila syarat objektif tidak terpenuhi maka perjanjian batal demi hukum.

Perjanjian menerapkan asas konsensual yang berarti kontrak terjadi pada saat terjadinya kesepakatan. Menurut Salim H.S, kesepakatan adalah persesuaian pernyataan kehendak antara satu orang atau lebih dengan pihak lainnya, yang sesuai itu adalah pernyataannya karena kehendak itu tidak dapat dilihat/diketahui orang lain. ${ }^{14}$ Perjanjian harus dibuat dalam kesadaran dan kerelaan kedua belah pihak. Pasal 1321 KUH Perdata pula menegaskan bahwa perjanjian tidak mempunyai kekuatan jika diberikan karena kekhilafan atau diperoleh dengan paksaan atau penipuan. Kesepakatan antara para pihak menjadikan perjanjian tersebut dianggap sebagai undang-undang bagi kedua belah pihak. ${ }^{15}$ Para pihak harus menghormati perjanjian tersebut dan tidak dapat ditarik tanpa kesepakatan kedua belah pihak sebagai penerapan asas pacta sunt servanda. ${ }^{16}$
Perjanjian fidusia dibuat dengan akta notaris yang dibacakan di hadapan dan ditandatangani para pihak secara sadar sebagai bentuk persetujuan atas isi dari akta tersebut. Sebagaimana prinsip perjanjian apabila salah satu pihak tidak menyetujui klausul-klausul dalam perjanjian tersebut dapat mengajukan keberatan dan penawaran kesepakatan dengan pihak lain dan kalau pun tidak ditemukan titik temu antara kedua belah pihak maka salah satu pihak dapat memutuskan untuk tidak menandatangani perjanjian tersebut atau dengan kata lain tidak mengikatkan diri dalam perjanjian tersebut. Ketika kreditor dan debitor menandatangani perjanjian fidusia yang berarti terdapat persesuaian kehendak antara keduanya maka perjanjian tersebut mengikat kedua belah pihak dan menimbulkan hak dan kewajiban bagi para pihak. ${ }^{17}$

Tidak hanya diwujudkan dalam akta notaris 18 namun akta tersebut wajib pula didaftarkan pada Kantor Pendaftaran Fidusia ${ }^{19}$ untuk kemudian diterbitkan Sertifikat Jaminan Fidusia sebagai bukti telah terjadi jaminan fidusia20. Pendaftaran pada Kantor Pendaftaran Fidusia merupakan perwujudan dari asas publisitas dan kepastian hukum bagi kreditor dan debitor. ${ }^{21}$ Asas publisitas bertujuan untuk mengumumkan kepada

\footnotetext{
14 Salim H.S, Perancangan Kontrak dan Memorandum of Understanding (MoU) (Ed. 1, Sinar Grafika 2006) 9.

15 Pasal 1338 ayat (1) KUH Perdata berbunyi: "Semua perjanjian yang dibuat secara sah berlaku sebagai undang-undang bagi mereka yang membuatnya"

16 Muhammad Noor, 'Penerapan Prinsip-Prinsip Hukum Perikatan Dalam Pembuatan Kontrak' (2015) 14 (1) Jurnal Mazahib 89, 91.

17 Kifni Kafa Rufaida dan Rian Sacipto, 'Tinjauan Hukum Terhadap Eksekusi Objek Jaminan Fidusia Tanpa Titel Eksekutorial Yang Sah' (2019) 4 (1) Jurnal Refleksi Hukum 21, 26.

Pasal 4 UU No. 42 Tahun 1999.

Pasal 12 UU No. 42 Tahun 1999.

Pasal 14 ayat (1) UU No. 42 Tahun 1999.

Hudiyanto, Riri Lastiar Situmorang, Aji Prasetyo, dan Rija Fathul Bari, Penguatan Perlindungan Konsumen Dalam Penggunaan Jaminan Fidusia (Ed. 1, Otoritas Jasa Keuangan 2018) 7.
} 
masyarakat mengenai status kepemilikan suatu hak. Asas ini merupakan pencerminan dari prinsip keadilan diantara pihak-pihak yang terkait dalam jaminan fidusia, yaitu kreditor, debitor dan pihak ketiga yang memiliki kepentingan terhadap benda jaminan. Dengan Sertifikat Jaminan Fidusia, kreditor memiliki legalitas kepemilikan hak milik atas benda jaminan dari debitor sebagai bukti hak mendahului atas kreditor-kreditor lainnya sedangkan bagi debitor, sertifikat tersebut secara legalitas sebagai bentuk perlindungan hukum apabila kreditor melanggar ketentuan di dalamnya. Ketika kreditor bertindak sewenang-wenang dalam hal pelaksanaan eksekusi yang tidak sesuai dengan perjanjian maka debitor dapat mengajukan upaya hukum ke pengadilan. Kreditor dilarang mengambil paksa objek fidusia dari debitor karena merupakan perbuatan main hakim sendiri (eigenrichting) yang dilarang oleh undang-undang, kreditor wajib mengajukan permohonan eksekusi Sertifikat Fidusia kepada Ketua Pengadilan Negeri. ${ }^{22}$

Perlindungan hukum yang seimbang antara kreditor dan debitor memiliki bentuk yang berbeda. Dengan Sertifikat Jaminan Fidusia, kreditor memiliki perlindungan hukum atas hak kepemilikan terhadap objek jaminan fidusia termasuk pelaksanaan eksekusi apabila debitor telah cidera janji. Sedangkan debitor tetap memiliki perlindungan hukum terhadap bendanya sebagai objek jaminan fidusia apabila kreditor berlaku sewenang-wenang yang tidak sesuai dengan perjanjian. Dengan menggunakan Sertifikat Jaminan Fidusia, debitor dapat memiliki hak untuk mengajukan/mendapat kesempatan pembelaan diri atas adanya dugaan telah cidera janji (wanprestasi).

Berdasarkan konstruksi hukum tersebut maka tidak benar apabila MK menyatakan bahwa Pasal 15 ayat (2) UU No. 42 Tahun 1999 sebagai norma yang memberikan titel eksekutorial Sertifikat Jaminan Fidusia memiliki cacat konstitusional karena tidak mencerminkan adanya perlindungan hukum yang seimbang antara pihakpihak yang terikat dalam perjanjian fidusia. MK menggambarkan bahwa titel eksekutorial hanya memberikan hak eksklusif kepada kreditor sedangkan debitor diabaikan haknya untuk mengajukan atau mendapat kesempatan pembelaan diri atas adanya dugaan telah cidera janji (wanprestasi) dan kesempatan mendapatkan hasil penjualan objek jaminan fidusia dengan harga yang wajar. Kendati kreditor melalui Sertifikat Jaminan Fidusia memiliki hak untuk secara langsung melakukan eksekusi terhadap objek fidusia, namun kreditor tidak dapat berlaku secara sewenangwenang tetapi terikat dengan isi perjanjian salah satunya mengenai kapan dan dalam kondisi bagaimana kreditor tersebut dapat melakukan eksekusi. Hal-hal tersebut telah diatur sebelumnya dalam perjanjian fidusia yang dalam pembuatannya telah memenuhi kesepakatan bebas dari para pihak tanpa adanya ancaman atau paksaan.

Di sisi lain, Sertifikat Jaminan Fidusia memberikan perlindungan pula kepada debitor apabila hak-hak diingkari. Apabila dalam proses pembuatan perjanjian debitor merasa da-

22 Pendapat Prof. Dr. Sutan Remy Sjahdeini, S.H., FCBArb dalam Putusan Mahkamah Konstitusi Republik Indonesia Nomor 18/PUU-XVII/2019, Mahkamah Konstitusi, 6 Januari 2020. 
lam ancaman atau paksaan dapat mengajukan pembatalan perjanjian dengan dasar Pasal $1321 \mathrm{KUH}$ Perdata, sehingga keduanya berada dalam posisi yang sama tanpa ada ketimpangan posisi yang dapat memaksakan kehendaknya kepada pihak yang lain. Mengenai pendapat MK yang menyatakan substansi perjanjian fidusia secara terselubung berlangsung dalam "keadaan tidak bebas secara sempurna dalam berkehendak," khususnya pada pihak debitor, menurut Penulis hal tersebut tidak dapat dijadikan alasan bahwa keduanya tidak memiliki perlindungan hukum yang sama sebagaimana layaknya hutang-piutang tentu ada pihak yang membutuhkan bantuan kepada pihak yang lain dan menjadi konsekuensi hukum pihak yang berhutang memiliki konsekuensi yang harus ditanggung apabila tidak memenuhi kewajibannya.

Terkait adanya perbedaan pendapat antara kreditor dan debitor sebenarnya sudah menjadi permasalahan yang biasa dalam praktik perbankan. Penyelesaiannya melalui gugatan di pengadilan dan pelaksanaan putusannya mengikuti mekanisme pelaksanaan putusan pengadilan yang telah berkekuatan hukum tetap. ${ }^{23}$ Pengalaman Pemohon yang telah mengajukan upaya hukum namun tidak diindahkan oleh kreditor hal tersebut merupakan ketidakpatuhan kreditor terhadap putusan pengadilan atau dapat dikategorikan sebagai perbuatan melawan hukum. ${ }^{24}$ Permasalahan tersebut merupakan kesalahan dalam penerapan undangundang bukan kesalahan norma karena mekanisme pengajuan gugatan perbedaan pendapat dan pelaksanaan eksekusi sebagaimana ketentuan HIR sejatinya telah dipraktikkan dalam perbankan. Kepolisian sebagai pihak yang bertanggungjawab melakukan pengamanan eksekusi fidusia harus memperhatikan adanya putusan pengadilan yang telah menyatakan kreditor melakukan perbuatan melawan hukum. Apabila terdapat kondisi sebagaimana dialami Pemohon seharusnya kepolisian menyarankan pengajuan eksekusi pelaksanaan putusan pengadilan di pengadilan negeri bukan membantu eksekusi tersebut. Hal ini dapat diatur dalam Peraturan Kepala Kepolisian Republik Indonesia tanpa melakukan perubahan terhadap ketentuan pasal dalam UU No. 42 Tahun 1999. MK seharusnya cukup menegaskan hal tersebut dalam putusannya bukan memberikan penafsiran baru. Perubahan penafsiran Mahkamah justru dapat mempersulit dan memperpanjang proses pelaksanaan eksekusi fidusia.

Mengenai konstitusionalitas $\mathrm{Pa}$ sal 15 ayat (3) UU No. 42 Tahun 1999, MK mempermasalahkan kepastian hukum terkait kapan dan siapa yang menentukan terjadinya "cidera janji". Permasalahan tersebut sesungguhnya telah mampu terjawab dengan mengacu pada Pasal 1238 KUH Perdata yang berbunyi:

"Si berutang adalah lalai, apabila ia dengan surat perintah atau dengan sebuah akta sejenis itu telah dinyatakan lalai, atau demi perikatannya sendiri, ialah jika ini menetapkan, bahwa si berutang harus dianggap lalai dengan lewatnya waktu yang ditentukan." 
Pasal tersebut menunjukkan dua kondisi kapan seseorang dianggap lalai atau cidera janji, yaitu:

1. Dalam hal perjanjian pokok telah menetapkan suatu waktu, tapi dengan lewatnya waktu tersebut (jatuh tempo) debitor belum juga melaksanakan kewajibannya.

2. Dalam hal perjanjian pokok tidak menentukan suatu waktu tertentu, lalu kreditor sudah memberitahukan kepada debitor untuk melaksanakan kewajiban atau prestasinya namun kreditor tetap juga tidak melaksanakannya kewajibanya kepada kreditor. ${ }^{25}$

Sejalan dengan hal tersebut, Ricardo Simanjuntak mengklasifikasikan cara menentukan cidera janji berdasarkan dua hal yakni berdasarkan kontrak dan berdasarkan hukum. Berdasarkan kontrak apabila diatur jelas dalam "klausula wanprestasi" (event of default) serta klausula "akibat wanprestasi", sedangkan berdasarkan hukum ditandai melalui surat peringatan (somasi) apabila tidak diatur dalam kontrak. ${ }^{26}$ Somasi (surat perintah /surat peringatan) merupakan langkah yang wajib dilakukan oleh kreditor dalam hal debitor melakukan cidera janji namun tidak ditentukan dalam kontrak. Pasal tersebut dikenal dalam hukum perdata sebagai ketentuan mengenai kewajiban kreditor untuk mengirimkan somasi terlebih dahulu sebelum mengajukan gugatan terhadap debitor yang cidera janji (wanprestasi) kepada Pengadilan Negeri, yaitu berupa surat perintah atau akta otentik untuk menyatakan debitor telah lalai (cidera janji/ wanprestasi). Menurut Sutan Remy Sjahdeini ketentuan Pasal 1238 KUH Perdata merupakan ketentuan yang tidak dapat disimpangi dengan membuat klausul dalam perjanjian di antara mereka untuk kreditor dibebaskan dari ketentuan Pasal tersebut. Dalam hukum perdata, ketentuan Pasal 1238 KUH Perdata tersebut merupakan hukum yang memaksa (dwingend recht). ${ }^{27}$ Apabila kreditor melakukan tindakan tidak didasarkan pada dua kondisi yang dikatakan sebagai wanprestasi tersebut, debitor berhak mengajukan gugatan dan berhak atas pengembalian biaya, ganti rugi, dan bunga berdasarkan Pasal 1266 KUH Perdata yang berbunyi "Syarat batal dianggap selalu dicantumkan dalam persetujuan yang timbal balik, apabila salah satu pihak tidak memenuhi kewajibannya. Dalam hal demikian persetujuan tidak batal demi hukum, tetapi pembatalan harus dimintakan kepada Pengadilan". 28 Dengan demikian kriteria cidera janji telah sedemikian rupa diatur baik dalam perjanjian maupun berdasarkan hukum, sehingga tidak ada lagi alasan debitor tidak mengetahui hal tersebut. MK yang mempertanyakan kepastian hukum perihal cidera janji menunjukkan bahwa MK tidak memahami atau setidaknya mengesampingkan konsep cidera janji yang telah diatur dalam KUH Perdata. Pengesampingan ini yang kemudian mengarahkan pendapat MK bahwa

25 Putusan Mahkamah Konstitusi Republik Indonesia Nomor 18/PUU-XVII/2019, Mahkamah Konstitusi, 6 Januari 2020.

26 Ricardo Simanjuntak, 'Putusan Mahkamah Konstitusi No. 18/PUU-XVII/2019 dan Konsekuensinya Terhadap Aktivitas Kredit dan Pembiayaan serta Permasalahannya dalam Kepailitan' (Jaminan Fidusia Pasca Putusan Mahkamah Konstitusi, Surabaya, Februari 2020).

27 Putusan Mahkamah Konstitusi Republik Indonesia Nomor 18/PUU-XVII/2019, Mahkamah Konstitusi, 6 Januari 2020. 
Pasal 15 ayat (3) UU No. 42 Tahun 1999 menghilangkan hak-hak debitor untuk melakukan pembelaan diri, padahal apabila memahami Pasal 1238 KUH Perdata maka tidak mungkin muncul argumentasi penghilangan hak-hak debitor. Megenai kekhawatiran MK yang sering kali muncul adanya perbuatan "paksaan" dan "kekerasan" dari orang yang mengaku sebagai pihak yang mendapat kuasa untuk menagih pinjaman utang debitor sehingga melahirkan perbuatan sewenangwenang, Penulis tegaskan kembali bahwa hal tersebut merupakan permasalahan penerapan pasal sehingga dapat diajukan gugatan ke pengadilan tanpa perlu menyatakan Pasal 15 ayat (3) UU No. 42 Tahun 1999 sebagai inkonstitusional bersyarat. MK cukup menegaskan kembali konsep cidera janji di KUH Perdata. Dengan demikian dua alasan fundamental yang menyebabkan Pasal 15 ayat (2) dan ayat (3) diputuskan sebagai inkonstitusional bersyarat sejatinya telah terjawab.

\section{Implikasi Putusan Nomor 18/PUU- XVII/2019 Terhadap Asas Hukum Kebendaan Jaminan Fidusia}

Jaminan Fidusia merupakan perjanjian ikutan (accesoir) dari suatu perjanjian pokok dalam hal ini perjanjian pinjam meminjam. Kreditor dan debitor jaminan fidusia melahirkan hubungan perikatan, yang menerbitkan hak bagi kreditor untuk meminta penyerahan kepemilikan barang jaminan dari debitor dan kewajiban bagi kreditor untuk memberikan sesuatu karena debitor menyerahkan objek jaminan fidusia. ${ }^{29}$ Objek jaminan fidusia merupakan jaminan dari debitor terhadap pelunasan kewajiban debitor kepada kreditor yang telah melakukan pelunasan atas objek pinjam meminjam. Jaminan diberikan kepada kreditor untuk menimbulkan keyakinan bahwa debitor akan memenuhi kewajiban yang dapat dinilai dengan uang yang timbul dari suatu perikatan. ${ }^{30}$ Sri Soedewi menyebutkan kedudukan perjanjian penjaminan sebagai perjanjian yang bersifat accessoir bertujuan untuk memberikan rasa aman terhadap kreditur. ${ }^{31}$ Jaminan harus dilihat sebagai kebutuhan kreditor untuk memperkecil risiko apabila debitor tidak mampu menyelesaikan semua kewajiban yang timbul dari perjanjian pokok.

Mengingat begitu pentingnya jaminan sebagai bentuk kepercayaan kreditor kepada debitor, Tan Kamelo berpendapat bahwa salah satu asas penting jaminan fidusia yakni, kemudahan dalam eksekusi. ${ }^{32}$ Eksekusi diperlukan guna menjamin pelaksanaan prestasi debitor sebagaimana yang telah diperjanjikan dalam perjanjian pokoknya berupa perjanjian pinjam meminjam. ${ }^{33}$ Tindakan eksekutorial dalam jaminan fidusia dilakukan melalui proses parate executie yaitu kewenangan yang

29 M. Yasir, 'Aspek Hukum Jaminan Fidusia' (2016) 3 (1) Jurnal Salam: Jurnal Sosial dan Budaya Syar-i 75, 83.

30 Hartono Hadisoeprapto dalam Junaidi Abdullah, 'Jaminan Fidusia di Indonesia (Tata Cara Pendaftaran dan Eksekusi)’ (2016) 4 (2) Junal Bisnis dan Manajemen Islam 115, 116.

31 Sri Soedewi Masjchoen Sofwan, Hukum Jaminan Fidusia Pedoman Praktis, (Ed. 1, Universitas Diponegoro 1999) 14.

32 Tan Kamelo, Hukum Jaminan Fidusia (Ed. 1, Alumni 2006) 171.

33 Putusan Mahkamah Konstitusi Republik Indonesia Nomor 18/PUU-XVII/2019, Mahkamah Konstitusi, 6 Januari 2020. 
dimiliki kreditur untuk menjual barang jaminan di muka umum bila debitor wanprestasi tanpa ada fiat atau ijin Ketua Pengadilan Negeri. ${ }^{34}$ Kemudahan eksekusi tersebut penting guna menarik kreditor untuk memberikan dananya dalam bentuk pinjaman disebabkan adanya keyakinan dan kepastian hukum bagi kreditor bahwa debitor akan memenuhi kewajibannya dalam perjanjian dan apabila tidak maka kreditor akan mendapatkan pelunasan kewajiban debitor melalui eksekusi benda yang dijadikan jaminan. Tanpa adanya kemudahan ini, kreditor tentunya enggan untuk memberikan dananya dalam bentuk pinjaman kepada debitor.

Kemudahan eksekusi dapat diterima mengingat bahwa objek jaminan masih berada dalam penguasaan debitor. Jaminan fidusia berbeda dengan gadai dimana objek jaminan gadai berada dalam penguasaan kreditor sehingga kreditor dapat sewaktuwaktu melakukan eksekusi terhadap objek yang telah berada di bawah penguasaannya. Dengan objek jaminan fidusia yang tidak berada di bawah penguasaan kreditor maka sangat rentan objek jaminan tersebut, khususnya benda bergerak, untuk dialihkan kepada pihak ketiga secara sepihak. Di sisi lain, dari sifat bendanya, benda bergerak mudah hilang, rusak, atau hal lain yang mengakibatkan penurunan nilai harga sehingga eksekusi perlu dilakukan dengan proses yang sederhana, waktu yang cepat, dan biaya murah. Para kreditor tidak seharusnya dibebani dengan biaya yang besar untuk melakukan proses eksekusi, terlebih lagi objek jaminan fidusia umumnya adalah benda bergerak yang nilainya tidak terlalu tinggi dibandingkan dengan benda tetap. Dengan nilai yang tidak terlalu tinggi tersebut jangan sampai kreditor dirugikan disebabkan biaya untuk melakukan eksekusi dalam hal debitor wanprestasi jauh lebih tinggi dibandingkan dengan nilai bendanya. 35 Dengan parate executie dapat memberikan perlindungan hukum terhadap hak-hak kreditor apabila debitor cidera janji. ${ }^{36}$ Menurut Munir Fuady, eksekusi jaminan fidusia mengandung kepastian hukum karena eksekusi dapat dilakukan dengan sederhana dan efisien sebagai ciri dari jaminan hutang kebendaan. ${ }^{37}$

Kekuatan eksekutorial dalam Sertifikat Jaminan Fidusia bertujuan untuk dapat memberikan kemudahan kreditor untuk menarik ganti rugi pembiayaan yang diberikan kepada debitor. ${ }^{38}$ Sebagai pendukung kemudahan tersebut, Pasal 20 UU No. 42 Tahun 1999 menegaskan bahwa jaminan fidusia mengikuti kemana pun dan di tangan siapa pun benda objek jaminan fidusia tersebut berada (asas droit de suite). Jaminan fidusia dapat dipertahankan terhadap siapa pun dan berhak menuntut siapa saja yang mengganggu hak tersebut. ${ }^{39} \mathrm{Hal}$ ini merupakan jaminan bagi kreditor sebagai pemilik hak yuridis atas objek jaminan fidusia sehingga akan mem-

\footnotetext{
$34 \quad$ Rachmadi Usman, Hukum Jaminan Keperdataan (Ed. 1, Sinar Grafika 2008) 229.

35 Ibid.

$36 \quad$ Ibid.

$37 \quad$ Munir Fuady, Jaminan Fidusia (Ed. 1, Citra Aditya Bakti 2000) 57.

38 Muhammad Maksum, 'Penerapan Jaminan Fidusia Dalam Kontrak Pembiayaan Syariah' (2015) 3 (1) Jurnal Cita Hukum 1, 2.

39 I Made Sarjana, Desak Putu Dewi Kasih, I Gusti Ayu Kartika, 'Menguji Asas Droit De Suite Dalam Jaminan Fidusia' (2015) 4 (3) Jurnal Magister Hukum Udayana 425, 430.
} 
berikan kepastian hukum bagi kreditor untuk menerima pelunasan utang dari hasil penjualan objek jaminan fidusia apabila terjadi cidera janji oleh penerima fidusia. ${ }^{40}$ Kepastian hukum tersebut ditekankan pula dalam Pasal 30 UU No. 42 Tahun 1999 bahwa debitor wajib menyerahkan benda yang menjadi objek jaminan fidusia dalam rangka pelaksanaan eksekusi jaminan fidusia. Apabila debitor cidera janji, kreditor mempunyai hak untuk menjual objek jaminan fidusia tersebut atas kekuasaannya sendiri41. Kewenangan untuk menjual benda debitor merupakan pelaksanaan prinsip parate executie dalam hak kebendaan sekaligus menjadi keistimewaan yang diberikan undang-undang kepada kreditor pemegang hak kepemilikan sebagai hak didahulukan dari kreditor lain (asas droit de preference) untuk mengambil pelunasan piutangnya atas hasil eksekusi benda debitor yang telah wanprestasi tersebut. Menurut Subekti, parate executie adalah menjalankan sendiri atau mengambil sendiri oleh kreditor tanpa melalui bantuan pengadilan negeri melainkan hanya berdasarkan bantuan Kantor Lelang Negara saja. ${ }^{42} \mathrm{Hal}$ ini memberikan kekuatan hukum bagi kreditor untuk melakukan eksekusi terhadap objek jaminan dari debitor.

Eksekusi objek jaminan fidusia dilakukan melalui pelelangan umum atau penjualan dibawah tangan atas kesepakatan debitor dan kreditor jika cara demikian dapat diperoleh harga tertinggi yang menguntungkan para pihak $^{43}$ atau dalam hal benda yang menjadi objek jaminan fidusia terdiri atas benda perdagangan atau efek yang dapat dijual di pasar atau di bursa, penjualannya dapat dilakukan di tempat-tempat tersebut sesuai dengan peraturan perundangundangan yang berlaku44. Pelaksanaan eksekusi jaminan fidusia dapat meminta bantuan keamanan kepada kepolisian didasarkan Peraturan Kepala Kepolisian Negara Republik Indonesia Nomor 8 Tahun 2011 tentang Pengamanan Eksekusi Jaminan Fidusia. Hasil penjelasan objek jaminan fidusia digunakan sebagai pelunasan utang debitor. Apabila penjualan benda tersebut melebihi utang debitor maka kreditor berkewajiban untuk mengembalikan sisa dari penjualan benda kepada debitor namun apabila hasil eksekusi tindak mencukupi pelunasan utang maka debitor tetap bertanggungjawab atas utang yang belum terbayar. ${ }^{45}$ Dengan demikian terdapat keadilan antara kreditor yang telah mendapatkan pelunasan piutang dari debitor sedangkan debitor dengan penjualan tersebut dapat memenuhi kewajiban pembayaran utangnya atau setidaknya pengurangan jumlah utang dan bahkan akan tetap mendapatkan pengembalian uang apabila hasil penjualan melebihi utangnya. Mekanisme eksekusi ini sekaligus menjawab pertimbangan MK terkait

40 Erich Kurniawan Widjaja dan Willian Tandya Putra, 'Karakteristik Hak Kebendaan Pada Objek Jaminan Fidusia Berupa Benda Persediaan' (2019) 12 (1) Jurnal Mercatoria 14, 20.

Pasal 29 UU No. 42 Tahun 1999.

42 Subekti dalam Markus Suryoutomo, Ahmad Hendroyono, dan Siti Maryam, 'Implementasi Model Parate Executie Atas Jaminan Fidusia: (Uji Model Eksekusi Jaminan Fidusia)' (2014) 43

(4) Jurnal Masalah Masalah Hukum 497, 498.

$43 \quad$ Pasal 29 angka (1) UU No. 42 Tahun 1999.

$44 \quad$ Pasal 31 UU No. 42 Tahun 1999.

$45 \quad$ Pasal 34 UU No. 42 Tahun 1999. 
perlindungan debitor untuk mendapatkan hasil penjualan objek jaminan fidusia dengan harga yang wajar.

Putusan Nomor 18/PUUXVII/2019 yang mengurangi kekuatan titel eksekutorial Sertifikat Jaminan Fidusia menyebabkan kemudahan eksekusi oleh kreditor tidak dapat dilaksanakan sebagaimana mestinya. Asas droit de suite, droit de preference dan parate executie terancam tidak dapat dijalankan sebagai akibat penafsiran MK yang menyatakan kekuatan eksekutorial Sertifikat Jaminan Fidusia tidak memiliki kekuatan hukum apabila tidak ada kesepakatan cidera janji dan kerelaan penyerahan objek jaminan dari debitor. Asas droit de suite yang memberikan jaminan hukum kepada kreditor terhadap kepemilikan objek jaminan terlepas kemana dan di tangan siapa pun objek tersebut berada guna pelunasan utang debitor tidak memiliki daya guna lagi apabila debitor tidak rela menyerahkannya kepada kreditor. ${ }^{46}$ Pasal 30 UU No. 42 Tahun 1999 sebagai kewajiban hukum debitor tidak lagi memiliki daya paksa atas dasar debitor dapat menolak penyerahan tersebut. Hak untuk menjual dan didahulukan dibanding kreditor lainnya (asas droit de preference) tidak lagi menjadi keistimewaan utama yang diberikan kepada kreditor mengingat akan semakin besarnya peran panitera pengadilan negara dalam melakukan pelelangan objek jaminan apabila melalui proses peradilan. Terakhir, parate executie yang prinsipnya merupakan suatu pelaksanaan eksekusi yang disederhanakan tanpa melibatkan pengadilan 47 akan terdegradasi dengan besarnya kemungkinan debitor akan lebih memilih eksekusi melalui pengadilan dengan berbagai potensi dalih yang dapat digunakan sebagaimana syarat yang diberikan MK dalam putusannya. Dengan demikian Putusan MK secara tidak langsung mendegradasi asasasas hukum kebendaan dalam jaminan fidusia yang merupakan nyawa dari jaminan kebendaan.

Konsekuensi yang dibawa oleh Putusan MK juga tidak sesuai dengan landasan historis munculnya asas parate executie di Parlemen Belanda. Parlemen Belanda mengesahkan parate executie sebagai bentuk penyelamatan rakyat kecil yang membutuhkan sekali kucuran pinjaman untuk menjalankan usahanya dan harus meminjam kepada lintah darat dengan bunga yang tinggi. Lembaga pembiayaan tidak mau memberikan pinjaman karena khawatir pinjaman tidak dapat dikembalikan. Melalui parate executie pemberi pinjaman diberikan kemudahan dalam melakukan penagihan apabila debitor wanprestasi dengan hak menjual sendiri tanpa bantuan pengadilan objek jaminan. Hal ini sebagai konsekuensi logis apabila kreditor tidak diberikan kemudahan dalam penagihan maka kreditor akan dikorbankan waktu dan dana untuk proses gugat menggugat penagihan di pengadilan. ${ }^{48}$ Dalam dimensi inter-

46 Frieda Husni Hasbullah, Hukum Kebendaan Perdata (Hak-Hak yang Memberi Kenikmatan) (Ed. 1, Ind-Hil-Co 2005) 52.

47 Offi Jayanti, Agung Darmawan, 'Pelaksanaan Lelang Tanah Jaminan Yang Terikat Hak Tanggungan' (2018) 20 (3) Kanun Jurnal Ilmu Hukum 457, 464.

48 Teddy Anggoro, 'Parate Eksekusi: Hak Kreditur, Yang Menderogasi Hukum Formil (Suatu Pemahaman Dasar dan Mendalam)’ (2007) 37 (4) Jurnal Hukum dan Pembangunan 535, 554555. 
nasional, putusan MK tidak sejalan dengan pedoman yang dikeluarkan The United Nations Commission on International Trade Law (UNCITRAL) dalam UNCITRAL Legislative Guide on Secured Transaction Law bahwa dalam transaksi berjaminan harus mempertimbangkan aspek untuk memfasilitas hak eksekusi pemegang hak jaminan secara efisien. ${ }^{49}$

\section{Implikasi Putusan Nomor 18/PUU- XVII/2019 Terhadap Proses Eksekusi Jaminan Fidusia}

MK yang mensyaratkan adanya kesepakatan cidera janji dan kesukarelaan penyerahan objek fidusia berpotensi digunakan debitor untuk memperpanjang proses eksekusi sehingga debitor tetap dapat memanfaatkan objek fidusia. Adanya perbedaan pendapat mengenai cidera janji menuntut adanya upaya hukum gugatan ke pengadilan negeri untuk mendapatkan keputusan wanprestasi, setelah diperoleh putusan telah terjadi wanprestasi atau tidak masih diperlukan kesukarelaan debitor untuk memenuhi kewajiban putusan pengadilan tersebut. Apabila debitor tidak juga memenuhi kewajiban tersebut maka kreditor harus melakukan permohonan pelaksanaan eksekusi putusan pengadilan tersebut. Di sisi lain, apabila debitor telah mengakui adanya cidera janji namun tidak dengan sukarela menyerahkan benda yang menjadi objek fidusia maka kreditor tidak dapat lantas meminta bantuan ke kepolisian tetapi harus mengajukan permohonan pelaksaan eksekusi sertifikat jaminan fidusia tersebut. Mekanisme pelak- saan eksekusi fidusia menjadi berlarut-larut dan membutuhkan tambahan biaya yang harus dikeluarkan.

Proses gugatan di Pengadilan Negeri membutuhkan proses yang panjang mulai pendaftaran gugatan, penunjukan majelis hakim, penunjukan panitera pengganti, penetapan waktu sidang, proses persidangan, jawab jinawab, pembuktian, hingga didapatkan putusan pengadilan. Proses penyelesaian perkara pada Pengadilan Tingkat Pertama menurut Surat Edaran Mahkamah Agung (SEMA) Nomor 2 Tahun 2014 tentang Penyelesaian Perkara di Pengadilan Tingkat Pertama dan Tingkat banding Pada 4 (Empat) Lingkungan Peradilan paling lama 5 (lima) bulan. Waktu tersebut belum termasuk waktu dibutuhkan apabila dilakukan upaya hukum kasasi dan banding. Mengacu pada SEMA yang sama, waktu yang diberikan pada tingkat banding paling lama 3 (tiga) bulan, sedangkan jangka waktu maksimal penanganan perkara kasasi dan peninjauan kembali secara normatif menurut peraturan internal Mahkamah Agung sejak pengajuan permohonan ke Pengadilan Negeri sampai dengan dengan pengiriman salinan putusan ke Pengadilan Negeri Pengaju adalah 250 hari bahkan dalam praktiknya penanganan perkara kasasi bisa lebih lama dari jangka waktu yang sudah ditetapkan sendiri oleh Mahkamah Agung. ${ }^{50}$ Dengan demikian apabila diakumulasi dari tahap pertama di Pengadilan Negeri hingga tahap kasasi Mahkamah Agung bisa mencapai 490 hari atau lebih karena apabila dibutuhkan masih

\footnotetext{
$49 \quad$ Ibid.

50 Keputusan Ketua Mahkamah Agung Republik Indonesia Nomor : 214/KMA/SK/XII/2014 tentang Jangka Waktu Penanganan Perkara Pada Mahkamah Agung Republik Indonesia.
} 
dimungkinkan melebihi batas maksimal tersebut.

Setelah proses peradilan telah berakhir dan berkekuatan hukum tetap namun debitor tidak secara sukarela melaksanakan putusan tersebut maka dibutuhkan pelaksanaan eksekusi putusan. Eksekusi putusan perdata di Indonesia menggunakan ketentuan Pasal 195 sampai 224 Het Herziene Indonesische Reglement (HIR). Putusan pengadilan negeri dilaksanakan atas perintah dan di bawah pimpinan ketua pengadilan negeri yang memeriksa perkara itu ${ }^{51}$ berdasarkan permohonan eksekusi baik cara lisan maupun dengan surat. ${ }^{52}$ Ketua Pengadilan akan memeriksa dan melaksanakan permohonan eksekusi.53 Setelah diperiksa, Ketua Pengadilan akan memanggil pihak yang kalah itu serta menegurnya (aanmaning), supaya ia memenuhi keputusan itu dalam waktu yang ditentukan selama-lamanya delapan hari. ${ }^{44}$ Jika melewati waktu yang sudah ditentukan namun pihak yang kalah itu belum juga memenuhi putusan atau tidak menghadap setelah dilakukan panggilan yang sah maka Ketua Pengadilan akan memberi perintah dengan surat supaya disita objek jaminannya. ${ }^{55}$ Penyitaan dijalankan oleh panitera pengadilan negeri. ${ }^{56}$ Panitera dapat menyuruh membawa barang itu seluruhnya atau sebagian ke suatu tempat penyimpanan yang memadai. 57 Terhitung dari hari berita acara penyitaan barang itu, pihak yang disita barangnya tidak boleh lagi memindahkan, membebani atau menyewakan barang itu kepada orang lain.58 Panitera akan melakukan penjualan sesuai Pasal 19 atau Pasal 31 UU No. 42 Tahun 1999. Penjualan hendaknya dilaporkan kepada Ketua Pengadilan tentang hasil penjualan itu.59 Sekelumit penjabaran ini memperlihatkan bahwa model eksekusi fidusia pasca putusan Nomor 18/PUU-XVII/2019 memperpanjang prosedur sebelumnya, menambah biaya yang harus dikeluarkan dalam proses gugatan dan pelaksanaan eksekusi, memberi beban baru bagi lembaga pengadilan khususnya pengadilan negeri untuk memproses perkara jaminan kebendaan, dan pelaksanaan eksekusi akan bergantung pada bantuan panitera sehingga kreditor tidak dapat melakukan tindakan eksekusi secara langsung. Dampak yang lebih jauh lembaga jaminan kebendaan berpotensi mempersulit permohonan jaminan kebendaan atau setidaknya meningkatkan nilai dari piutang yang dapat dikenakan jaminan kebendaan demi mengantisipasi biaya yang lebih tinggi maupun proses yang lebih panjang, sehingga lembaga penjamin tidak dibebani dengan piutang yang kecil namun risiko pelaksanaan eksekusi yang lebih besar. Hal ini tidak sejalan dengan landasan terbentuknya lembaga jaminan fidusia yang dilatarbelakangi oleh kepentingan pembangunan di bidang ekonomi, terutama

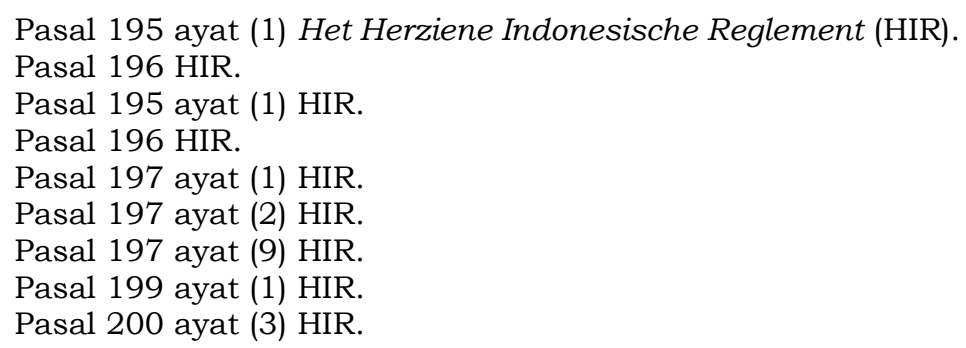


dalam menunjang kegiatan perkreditan karena berpotensi menurunnya kemudahan dalam prekreditan.

Berbagai pemaparan penulis sebelumnya telah menunjukkan bahwa alasan dalam pertimbangan Mahkamah tidak dapat diterima baik karena telah menyalahi atau mengesampingkan ketentuan secara normatif dan konseptual serta telah menyalahi landasan filosofis keberadaan jaminan fidusia yakni memberikan kemudahan proses eksekusi objek jaminan fidusia. UU Fidusia sebelumnya dikeluarkannya Putusan Nomor 18/PUU-XVII/2019 telah sesuai dengan landasan filosofis dan asas-asas hukum kebendaan. Dikeluarkannya Putusan Nomor 18/PUUXVII/2019 justru memperumit proses jaminan fidusia.

Putusan MK bersifat final dan mengikat sehingga tidak ada upaya hukum untuk menguji putusan tersebut. Maka satu-satunya cara untuk mengembalikan ruh jaminan fidusia yaitu dengan melakukan perubahan atas UU No. 42 Tahun 1999 oleh Dewan Perwakilan Rakyat (DPR) bersama Presiden dengan penegasan terhadap, pertama, kekuatan eksekutorial Sertifikat Jaminan Fidusia memiliki kekuatan yang sama dengan putusan pengadilan yang telah berkekuatan hukum tetap dengan tidak diwajibkan mengikuti mekanisme pelaksanaan eksekusi sebagaimana putusan pengadilan namun tetap memberikan kesempatan kepada debitor untuk mengajukan penolakan eksekusi apabila terdapat hal-hal yang dapat dijadikan alasan, serta, kedua, penegasan terhadap penafsiran cidera janji dengan mengacu Pasal 1238 KUH Perdata.
Di sisi lain, Penulis menyadari bahwa melakukan perubahan undang -undang membutuhkan kemauan politik pembentuk undang-undang dan membutuhkan proses yang panjang. Sebagai alternatif untuk mengurangi atau bahkan menghilangkan potensi kerugian kreditor selama menunggu perubahan undangundang tersebut terwujud, Penulis mengajukan beberapa hal diantaranya:

a. Perubahan Klausul Akta Notaris Penjaminan Kebendaan Fidusia

Mahkamah dalam putusannya mensyaratkan adanya kesepakatan cidera janji dan kerelaan debitor untuk menyerahkan objek jaminan sebelum kreditor mengeksekusi jaminan tersebut. Hal ini menunjukkan posisi yang krusial dari akta notaris sebagai pengikat kedua belah pihak. Akta notaris harus mampu menguraikan dengan cermat dan jelas berbagai hal terkait dengan fidusia dan jaminannya. Kreditor dan debitor harus memahami isi dari setiap klausul dan menyepakati setiap bagiannya sehingga tidak muncul adanya perbedaan penafsiran ketika terjadi permasalahan. Sebagai bentuk akomodir dari putusan MK perlu adanya penegasan klausul sebagaimana amanat putusan MK tersebut. Perjanjian fidusia nantinya harus ada klausula tambahan/perubahan yaitu:

1) memasukkan klausula yang menerangkan kondisi "wanprestasi/cidera janji oleh debitor" secara tegas;

2) jika debitor wanprestasi sebagaimana kondisi yang disebutkan pada poin (1), maka debitor secara sukarela atau atas kesadaran sendiri untuk menyerahkan jaminan tersebut kepada debitor untuk dijual 
oleh kreditor atas kekuasaan sendiri;

3) Jika ketentuan yang tersebut dalam poin (2) di atas tidak dilakukan oleh debitor, maka penggugat akan mengugat debitor ke pengadilan negeri. 60

Meskipun dalam perjanjian telah diatur ketentuan cidera janji tidak menutup kemungkinan guna memperumit proses eksekusi fidusia debitor tetap menolak menyerahkan jaminan fidusia secara sukarela maka perlu adanya klausul gugatan di pengadilan. Proses gugatan atau permohonan pelaksanaan eksekusi akan menjadi hal yang lazim dihadapi kreditor nantinya.

b. Gugatan Sederhana Sebagai Solusi Alternatif Pengajuan Gugatan

Gugatan wanprestasi debitor akan banyak diajukan kreditor khususnya terhadap debitor yang tidak mengakui wanprestasinya dan menolak menyerahkan jaminan fidusia secara sukarela. Banyak konsekuensi yang harus dibayar oleh kreditor dalam pengajuan gugatan diantaranya biaya panjar perkara, biaya yang harus dikeluarkan selama proses persidangan, biaya kuasa hukum apabila menggunakan jasa kuasa hukum, serta proses persidangan yang panjang dan rumit. Guna mewujudkan penyelenggaraan peradilan dengan asas sederhana, cepat, dan biaya ringan dengan adanya pembedaan nilai objek dan gugatan serta sederhana tidaknya pembuktian maka
Mahkamah Agung melalui Peraturan Mahkamah Agung Nomor 2 Tahun 2015 tentang Tata Cara Penyelesaian Gugatan Sederhana sebagaimana telah diubah dengan Peraturan Mahkamah Agung Nomor 4 Tahun 2019 tentang Perubahan Atas Peraturan Mahkamah Agung Nomor 2 Tahun 2015 tentang Tata Cara Penyelesaian Gugatan Sederhana (selanjutnya disebut Perma Gugatan Sederhana) memperkenalkan penyelesaian perkara melalui mekanisme Gugatan Sederhana. Gugatan Sederhana adalah tata cara pemeriksaan di persidangan terhadap gugatan perdata baik perkara cidera janji dan/atau perbuatan melawan hukum dengan nilai gugatan materiil paling banyak Rp. 500.000.000,00 (lima ratus juta rupiah) yang diselesaikan dengan tata cara dan pembuktiannya sederhana, kecuali perkara yang penyelesaian sengketanya dilakukan melalui pengadilan khusus atau sengketa hak atas tanah. ${ }^{61}$

Gugatan sederhana diperiksa oleh hakim tunggal dan penyelesaiannya paling lama 25 (dua puluh lima) hari sejak hari sidang pertama. ${ }^{62}$ Beberapa syarat formil yang harus dipenuhi untuk beracara dengan gugatan sederhana, yakni:

1) Penggugat dan tergugat tidak boleh lebih dari satu, kecuali memiliki kepentingan hukum yang sama. ${ }^{63}$

2) Penggugat dan tergugat berdomisili di daerah hukum Pengadilan yang sama. Dalam 'Putusan Mahkamah Konstitusi No. 18/PUU-XVII/2019 dan Konsekuensinya dalam Praktik Pembuatan Akta Fidusia serta Lelang Objek Jaminan Fidusia' (Jaminan Fidusia Pasca Putusan Mahkamah Konstitusi, Surabaya, Februari 2020).

$61 \quad$ Pasal 1 angka 1 juncto Pasal 3 Perma No. 4 Tahun 2019.

$62 \quad$ Pasal 5 ayat (3) 3 Perma No. 4 Tahun 2019.

$63 \quad$ Pasal 4 ayat (1) Perma No. 4 Tahun 2019. 
hal penggugat berada di luar wilayah hukum tempat tinggal atau domisili tergugat, penggugat dalam mengajukan gugatan menunjuk kuasa, kuasa insidentil, atau wakil yang beralamat di wilayah hukum atau domisili dari institusi penggugat. 64

3) Penggugat dan tergugat wajib menghadiri secara langsung setiap persidangan dengan atau tanpa didampingi oleh kuasa, kuasa inisdentil atau wakil dengan surat tugas dari institusi penggugat. 65

Di samping syarat formil tersebut, hakim melalui pemeriksaan pendahuluan yang menentukan apakah perkara tersebut adalah gugatan sederhana atau bukan, Apabila hakim berpendapat bahwa perkara bukanlah gugatan sederhana, maka dikeluarkan penetapan yang artinya pemeriksaan perkara tidak berlanjut. Atas penetapan hakim ini tidak dapat dilakukan upaya hukum apapun.66

Proses pemeriksaan gugatan sederhana tidak dapat diajukan tuntutan provisi, eksepsi, rekonvensi, intervensi, replik, duplik, atau kesimpulan. ${ }^{67}$ Upaya hukum yang tersedia hanya "keberatan" yang diajukan tergugat terhadap putusan verstek atau putusan tanpa hadirnya tergugat. 68 Terhadap putusan yang tidak diajukan keberatan maka putusan berkekuatan hukum tetap. ${ }^{69}$ Sebagai- mana prinsip putusan pengadilan perdata, putusan yang sudah berkekuatan hukum tetap dilaksanakan secara sukarela.70 Dalam hal tidak dilaksanakan secara sukarela, Ketua Pengadilan mengeluarkan penetapan aanmaning paling lambat 7 (tujuh) hari setelah menerima surat permohonan eksekusi71 kemudian Ketua Pengadilan menetapkan tanggal pelaksanaan aanmaning paling lambat 7 (tujuh) hari setelah penetapan aanmaning. ${ }^{72}$ Dalam hal kondisi geografis tertentu pelaksanaan aanmaning tidak dapat dilaksanakan dalam waktu 7 (tujuh) hari, Ketua Pengadilan dapat menyimpangi katentuan batas waktu tersebut. ${ }^{73}$ Pelaksanaan putusan dilaksanakan berdasarkan ketentuan hukum acara perdata yang berlaku. Bedanya hanya terletak pada batas waktu pelaksanaan aanmaning, kalau di HIR selama 8 (delapan) hari sedangkan di Perma Gugatan Sederhana selama 7 (tujuh) hari.

Ketentuan batas waktu dalam Perma Gugatan Sederhana yang bersifat imperatif dapat mengefektifkan proses penyelesaian dan menjamin kepastian hukum yang lebih cepat. Namun perlu diingat bahwa gugatan sederhana hanya dapat dijadikan solusi apabila nilai gugatannya tidak melebihi Rp. 500. 000.000,- (lima ratus juta rupiah), artinya sengketa dengan nilai objek jaminan lebih dari nilai tersebut tidak

\footnotetext{
64 Pasal 3 dan 3a Perma No. 4 Tahun 2019.

Pasal 4 Perma No. 4 Tahun 2019.

Pasal 11 Perma No. 4 Tahun 2019.

Pasal 17 Perma No. 4 Tahun 2019.

Pasal 13 ayat (3) Perma No. 4 Tahun 2019.

Pasal 31 ayat (1) Perma No. 4 Tahun 2019.

Pasal 31 ayat (2) Perma No. 4 Tahun 2019.

Pasal 31 ayat (2a) Perma No. 4 Tahun 2019.

Pasal 31 ayat (2b) Perma No. 4 Tahun 2019.

Pasal 31 ayat (2) huruf c Perma No. 4 Tahun 2019.
} 
dapat diajukan permohonan gugatan sederhana sehingga tidak ada jalan lain selain menggunakan gugatan perdata biasa. Dengan demikian konsekuensi proses sistem peradilan gugatan biasa dengan adanya kemungkinan upaya hukum banding dan kasasi tidak dapat dielakkan.

Pengoptimalan klausul-klausul dalam akta notaris sebagai dasar perjanjian dengan mengatur ketentuan-ketentuan yang tegas dapat memperkecil potensi perbedaan pendapat serta memberikan kedudukan hukum yang tegas antara para pihak. Akta notaris upaya nonlitigasi utama guna menghindari penyelesaian secara litigasi. Namun apabila proses litigasi tidak dapat dihindarkan maka dapat memanfaatkan mekanisme gugatan sederhana sebagai solusi mempercepat proses dengan tetap memperhatikan syarat-syarat yang ditentukan. Dengan demikian solusi yang diberikan dapat menutup celah secara nonlitigasi maupun litigasi.

\section{PENUTUP}

Putusan MK Nomor 18/PUUXVII/2019 menyatakan Sertifikat Jaminan Fidusia tidak memiliki kekuatan eksekutorial tanpa adanya kesepakatan cidera janji antar debitor dan kreditor dan debitor tidak secara sukarela menyerahkan objek jaminan fidusia. Apabila Sertifikat Jaminan Fidusia tidak memenuhi salah satu atau keduanya maka diperlukan upaya gugatan di pengadilan dan permohonan pelaksanaan eksekusi sebagaimana putusan pengadilan yang berkekuatan hukum tetap. Perubahan penafsiran kekuatan eksekutorial dalam Sertifikat Jaminan Fidusia berpotensi mengurangi prinsip hak kebendaan dalam jaminan fidusia yakni droit de suite, droit de preference, dan parate executie. Implikasi dari putusan tersebut menghilangkan karakteristik kemudahan eksekusi jaminan karena proses pelaksanaan sertifikat jaminan fidusia semakin panjang, membutuhkan biaya tambahan, memberikan beban baru bagi pengadilan, pelaksanaan eksekusi akan bergantung pada bantuan panitera hingga dalam jangka panjang berpotensi lembaga jaminan kebendaan mempersulit jaminan kebendaan. Solusi yang Penulis ajukan yakni melakukan perubahan atas UU No. 42 Tahun 1999 dengan penegasan kekuatan eksekutorial Sertifikat Jaminan Fidusia dan penafsiran cidera janji. Di samping menantikan perubahan undang-undang tersebut terwujud Penulis memberikan solusi kepada kreditor untuk melakukan penambahan atau perubahan klausul dalam Akta Notaris Jaminan Fidusia dengan mengakomodir syarat-syarat dalam putusan MK dan memanfaatkan mekanisme gugatan sederhana guna mempercepat proses penyelesaian perkara.

\section{DAFTAR BACAAN}

\section{Buku}

Fuady M, Hukum Bisnis Dalam Teori dan Praktek, (Citra Aditya Bakti 1996).
----------, Jaminan Fidusia (Ed. 1, Citra Aditya Bakti 2000).

Harun B, Penyelesaian Sengketa Kredit Bermasalah, Solusi Hukum (Legal Action) dan Alternatif Penyelesaian Segala Jenis Kredit Bermasalah (Pustaka Yustisia 2010).

Hasbullah FH, Hukum Kebendaan Perdata (Hak-Hak yang Memberi 
Kenikmatan) (Ed. 1, Ind-Hil-Co 2005).

Hudiyanto, Situmorang RL, Prasetyo A, dan Bari RF, Penguatan Perlindungan Konsumen dalam Penggunaan Jaminan Fidusia (Ed. 1, Otoritas Jasa Keuangan 2018).

Kamelo, Tan, Hukum Jaminan Fidusia (Ed. 1, Alumni 2006).

Salim H.S, Perancangan Kontrak dan Memorandum of Understanding (MoU) (Sinar Grafika 2006).

Sofwan SSM, Hukum Jaminan Fidusia Pedoman Praktis (Universitas Diponegoro 1999).

Usman, Rachmadi, Hukum Jaminan Keperdataan (Ed. 1, Sinar Grafika 2008).

\section{Artikel Jurnal}

Abdullah J, 'Jaminan Fidusia di Indonesia (Tata Cara Pendaftaran dan Eksekusi)' (2016) 4 (2) Junal Bisnis dan Manajemen Islam.

Anggoro T, 'Parate Eksekusi: Hak Kreditur, Yang Menderogasi Hukum Formil (Suatu Pemahaman Dasar dan Mendalam)' (2007) 37 (4) Jurnal Hukum dan Pembangunan.

Jayanti O, Darmawan A, 'Pelaksanaan Lelang Tanah Jaminan Yang Terikat Hak Tanggungan' (2018) 20 (3) Kanun Jurnal Ilmu Hukum.

Maksum M, 'Penerapan Jaminan Fidusia Dalam Kontrak Pembiayaan Syariah' (2015) 3 (1) Jurnal Cita Hukum.

Noor M, 'Penerapan Prinsip-Prinsip Hukum Perikatan Dalam Pembuatan Kontrak' (2015) 14 (1) Jurnal Mazahib.
Rufaida KK dan Sacipto R, 'Tinjauan Hukum Terhadap Eksekusi Objek Jaminan Fidusia Tanpa Titel Eksekutorial Yang Sah' (2019) 4 (1) Jurnal Refleksi Hukum.

Sarjana IM, Kasih DPD, dan Kartika IGA, 'Menguji Asas Droit De Suite Dalam Jaminan Fidusia' (2015) 4 (3) Jurnal Magister Hukum Udayana.

Suryoutomo M, Hendroyono A, dan Maryam S, 'Implementasi Model Parate Executie Atas Jaminan Fidusia: (Uji Model Eksekusi Jaminan Fidusia)' (2014) 43 (4) Jurnal Masalah Masalah Hukum.

Widjaja EK dan Putra WT, 'Karakteristik Hak Kebendaan Pada Objek Jaminan Fidusia Berupa Benda Persediaan' (2019) 12 (1) Jurnal Mercatoria.

Yasir M, 'Aspek Hukum Jaminan Fidusia' (2016) 3 (1) Jurnal Salam: Jurnal Sosial dan Budaya Syar-i.

\section{Artikel Koran}

Wicaksono A, 'Putusan MK: Penarikan Barang Leasing Harus Melalui Pengadilan' CNN Indonesia (Jakarta, 13 Januari 2020) <https://www.cnnindonesia.com / nasional/20200113112552-12464820/putusan-mk-penarikanbarang-leasing-harus-melaluipengadilan> diakses 22 April 2020.

\section{Seminar/Konferensi}

Adjie H, 'Putusan Mahkamah Konstitusi No. 18/PUUXVII/2019 dan Konsekuensinya dalam Praktik Pembuatan Akta 
Fidusia serta Lelang Objek Jaminan Fidusia' (Seminar Jaminan Fidusia Pasca Putusan Mahkamah Konstitusi, Surabaya, Februari 2020).

Simamora YS, 'Prinsip Eksekutabilitas Atas Jaminan Fidusia Pasca Putusan MK' (Seminar Jaminan Fidusia Pasca Putusan Mahkamah Konstitusi, Surabaya, Februari 2020).

Simanjuntak R, 'Putusan Mahkamah Konstitusi No. 18/PUUXVII/2019 dan Konsekuensinya Terhadap Aktivitas Kredit dan Pembiayaan serta Permasalahannya dalam Kepailitan' (Seminar Jaminan Fidusia Pasca Putusan Mahkamah Konstitusi, Surabaya, Februari 2020).

Suleksono E, 'Jaminan Fidusia di Perbankan Pasca Putusan Mahkamah Konstitusi' (Seminar Jaminan Fidusia Pasca Putusan Mahkamah Konstitusi, Surabaya, Februari 2020).

\section{Putusan Pengadilan}

Putusan Mahkamah Konstitusi Republik Indonesia Nomor 18/PUU-XVII/2019, Mahkamah Konstitusi, 6 Januari 2020.

Standard Chartered Bank vs. Ir. Victoria Silvia Beltiny, No. 3192 K/Pdt/2012, Mahkamah Agung, 3 Oktober 2013.

\section{Peraturan Perundang-Undangan}

Het Herziene Indonesische Reglement (HIR).

Kitab Undang-Undang Hukum Acara Perdata.

Undang-Undang Nomor 42 Tahun 1999 tentang Jaminan Fidusia.
Peraturan Mahkamah Agung Nomor 2 Tahun 2015 tentang Tata Cara Penyelesaian Gugatan Sederhana.

Peraturan Mahkamah Agung Nomor 4 Tahun 2019 tentang Perubahan Atas Peraturan Mahkamah Agung Nomor 2 Tahun 2015 tentang Tata Cara Penyelesaian Gugatan Sederhana.

Keputusan Ketua Mahkamah Agung Republik Indonesia Nomor: 214/KMA/SK/XII/2014 tentang Jangka Waktu Penanganan Perkara Pada Mahkamah Agung Republik Indonesia. 